\title{
Evaluation of Pear Varieties for Physiochemical Traits Grown under Climatic Conditions of Soon Valley, Pakistan
}

\author{
Malik Mohsin Abbas', Hira Faiz¹, Muhammad Maaz Aziz ${ }^{1}$, Sahar Rashid1, Hameed Ullah², \\ Rashad Qadri ${ }^{3}$, Muhammad Azam ${ }^{3}$
}

\author{
${ }^{1}$ Horticultural Research Institute, Faisalabad, Pakistan \\ ${ }^{2}$ Horticultural Research Station, Murree, Pakistan \\ ${ }^{3}$ Institute of Horticultural Sciences, University of Agriculture Faisalabad, Faisalabad, Pakistan \\ Email: waseemrana_83pk@yahoo.com, Malikmohsin144@gmail.com
}

How to cite this paper: Abbas, M.M., Faiz, H., Aziz, M.M., Rashid, S., Ullah, H., Qadri, R. and Azam, M. (2018) Evaluation of Pear Varieties for Physiochemical Traits Grown under Climatic Conditions of Soon Valley, Pakistan. American Journal of Plant Sciences, 9, 2217-2226.

https://doi.org/10.4236/ajps.2018.911160

Received: July 28, 2018

Accepted: October 16, 2018

Published: October 19, 2018

Copyright $\odot 2018$ by authors and Scientific Research Publishing Inc. This work is licensed under the Creative Commons Attribution International License (CC BY 4.0).

http://creativecommons.org/licenses/by/4.0/

(C) (i) Open Access

\begin{abstract}
The study carried out aimed at characterizing the pear cultivars and to explore the specific cultivar most suitable to be commercially grown in Soon valley region. Nine pear varieties (Leconte, Bagugosha, Bartlet pear, Concord, Pear selection-1, Pear Red, Pear White, Kashmiri Nashpati and Kashmiri Nakh) were tested for their physiochemical quality attributes. The observations made during the study revealed that variety Bagugosha scored maximum $(7.95,8.10)$ in taste and flavor respectively. The same variety produced maximum fruit size $\left(5081 \mathrm{~mm}^{2}\right)$, fruit weight $(205 \mathrm{~g})$, soluble solid contents $(15 \%)$ and total sugars (9.56\%). However, fruit yield per plant was maximum $(98.80 \mathrm{~kg})$ in Bartlet pear variety and Bagugosha produced fruitweight of $60.20 \mathrm{~kg}$. Titratable acidity was determined maximum (0.44\%) in Kashmiri Nakh. Number of seeds were maximum (8.20) in Bartlet Pear as well as in Bgugosha. The exploration of this research study revealed that the Bagugosha is the prime quality cultivar to be suggested for commercial cultivation in Soon valley compared to all nine evaluated varieties.
\end{abstract}

\section{Keywords}

Pear, Physiological Traits, Climate, Soon Valley

\section{Introduction}

Fruits are appreciated for their delicious flavor, attractive appearance as well as the nutritional contents, especially vitamins and minerals. Pear ranks at second position after apple among the most commonly cultivated and consumed fruit of 
economic importance in temperate zones, across the globe [1].

Globally, pear (Pyrus spp.) is enjoyed as one of the oldest man cultivated fruit plant. This fruit is greatly appreciated by the consumers because of its high nutritional profile, low caloric value and delicious taste [2]. Pears are rich in macro and micro nutrients, and as well as an excellent source of vitamin $\mathrm{C}$ and dietary fiber [2] [3]. A fresh pear fruit of medium size weighing $100 \mathrm{~g}$ is packed with carbohydrates $(15.46 \mathrm{~g})$, protein $(0.38 \mathrm{~g})$, sugars $(9.80 \mathrm{~g})$, fat $(0.12 \mathrm{~g})$, vitamin C $(4.20 \mathrm{mg})$, magnesium $(11.00 \mathrm{mg})$, potassium $(119.00 \mathrm{mg})$, zinc $(0.10 \mathrm{mg})$, iron $(7.00 \mathrm{mg})$ and water contents $(83.71 \mathrm{~g})$ [4]. Mostly, pears are consumed fresh and may be used in processing of making jams, jellies, juices, puree and fruit wine. The pear fruit has also been traditionally used for remedial purpose intended for relieving constipation, alcoholism and cough along with moistening the lungs from more than 2000 years in Asian countries like China, Korea and Japan. There are more than 5000 identified pear varieties being cultivated around the globe, but only about 30 species have been cultivated worldwide. Different pears species possesses different nutritional profiles with numeroustastes and aromas. European pear (Pyrus communis) possesses relatively higher caloric value and sugar contents, whereas Asian pear (Pyrus pyrifolia, Pyrus bretschneideri Rehd.) usually contained more water with less account sugar and starch contents. Asian pears are distinguished as a healthy or nutritious fruit; however European pears are generally known for their delicious taste. Citric and malic acid are the major constituents of organic acids found in pear fruit [5].

In Pakistan, pear orchards are mostly established in the hills or on terraces and in the plans of Khyber Pakhtunkhwa (Peshawar Hazara and Mardan) [6]. Total area under pear fruit in Pakistan is 1820 hectares giving production 16,569 tons; however, only in Khyber Pakhtunkhwa province, pear holds an acreage of 1589 hectares and total production 16,087 tons [7]. In Punjab pear cultivation is confined to some areas of temperate climate on an area of 13 hectares only. [8] investigated that measurement of physical and chemical properties of pear fruit is helpful for the proper designing of different tools used for harvesting and packing. In addition, it plays important role to establish harvesting or maturity indices to evaluate the fruit quality. There are very little or no reports found on the varietal assessment studies regarding pear fruit. Also, no previous record is found for physiochemical characterization of varieties being cultivated in that particular area. Hence, the current study was designed to find the physio-chemical traits of main pear varieties to generate accurate information for growers, entrepreneurs, researchers and the ultimate consumers. The findings of the study will further provide the information about the most suitable pear cultivar to cultivate in that area.

\section{Materials and Methods}

The study was conducted on pear varieties for physic-chemical characterization. Fruits of nine pear varieties (Pear Leconte, Bagugosha, Bartlet pear, Concord, 
Pear selection-1, Pear Red, Pear White, Kashmiri Nashpati and Kashmiri Nakh) grown in Soon Valley were assessed for their physico-chemical characteristics (see the details in Table 1). Soon valley is situated nearly at the elevation of 2700 - $5000 \mathrm{ft}$ with mean maximum temperature is $42^{\circ} \mathrm{C}$ and minimum temperature $-3^{\circ} \mathrm{C}$ and average temperature remains in the range of $33^{\circ} \mathrm{C}$. This valley received average $350-500 \mathrm{~mm}$ average rain during the experiment period. The climatic conditions (Ave. maximum temperature $29.5^{\circ} \mathrm{C}$ and Ave. maximum temperature $16.1^{\circ} \mathrm{C}$ ) of the research area prevailed the time of fruit harvest. Healthy, mature and diseased free pear fruits were collected from each variety during the 2014-16, and in order to reduce excessive moisture loss during the transportation fruits covered in polyethylene bags. Fruits immediately transported to the laboratory of the Horticultural Research Station, Soon Valley for the determination of quality traits from each pear variety. The fruits were properly washed, air dried and again packed in the polyethylene bags, refrigerated and immediately analyzed for their sensory and biochemical properties.

\subsection{Biochemical Characteristics}

Total sugars, reducing and non-reducing were measured according to AOAC standard procedure [9]. Contents of total soluble solids ( ${ }^{\circ}$ Brix) were recorded in the pulp of each fruit sample with the help of digital refractometer (BX-1, Atago, Japan). Titratable acidity (TA) was calculated by taking an aliquot of $5 \mathrm{ml}$ juice and titrated against $0.1 \mathrm{~N} \mathrm{NaOH}$ and results were presented in percentage of malic acid.

\subsection{Physical and Geometric Properties}

Ten healthy, disease free pear fruits were selected from each cultivars and number of seeds and fruit weight were recorded by a digital weighing balance (SF-400A, China). Fruit dimension were recorded by measuring fruit length and width by a digital vernier caliper with an accuracy of $0.01 \mathrm{~mm}$. Fruit was cut into two pieces, seeds were extracted and number of seeds per fruit were counted.

\subsection{Sensory Evaluation/Organoleptic Properties}

Sensory evaluation for taste, flavour, fruit and flesh colour was carried out by a panel of members against a scale of 10 scores as established by [10]. Ten fruit samples were given to the members for sensory assessment. The panel members were permitted to check and taste again any fruit if desired in scoring of the fruits by allotting number from 1 - 10 to each fruit sample. Sensory evaluation was performed by fruit experts instead of non-technical consumers. The sample performa is given in Table 2.

\section{Hedonic scale rating}

Product. Variety

Date

Name of judge Signature.

Instructions: (Please read the instructions carefully before filling the blanks) 
1) This is an organoleptic analysis form for evaluation of pear fruits.

2) Please follow the numerical system for scoring of samples.

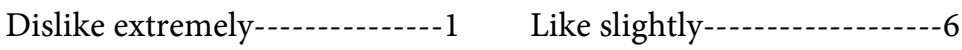

Dislike very much------------2 Like moderately--------------7

Dislike moderately-------------3 Like very much----------------8

Dislike slightly---------------4 Like extremely---------------9

Neither like nor dislike---------5

\subsection{Statistical Analysis}

The investigation was conducted under single factor Completely Randomized Design. The quantitative observations made were then arranged and data obtained was statistically analyzed by using analysis of variance (ANOVA) technique highest significant difference between treatments were assessed were done by Tukey's test through a computer statistical package Statistix 8.1 software as interpreted by following [11].

Table 1. Color of fruit and maturity time.

\begin{tabular}{ccc}
\hline Name of Variety & Color of fruit & Maturity Time \\
\hline Pear Leconte & Yellowish Green & August \\
Bagugosha & Yellowish Green & Late September \\
Bartlet Pear & Dark Yellow & Early October \\
Concord & Reddish Green & Late July \\
Pear Selection-1 & Yellowish & Late September \\
Pear Red & Whitish with Red Blush & Late September \\
Pear White & Greenish White & Late September \\
Kashmiri Nashpati & Greenish & Late October \\
Kashmiri Nakh & Green & Early October
\end{tabular}

Table 2. Hedonic scale for sensory assessment of pear fruits.

\begin{tabular}{|c|c|c|c|c|}
\hline Sample No. & Fruit color & Flesh color & Taste & Flavour \\
\hline \multicolumn{5}{|l|}{1.} \\
\hline \multicolumn{5}{|l|}{2.} \\
\hline \multicolumn{5}{|l|}{3.} \\
\hline \multicolumn{5}{|l|}{4.} \\
\hline \multicolumn{5}{|l|}{5.} \\
\hline \multicolumn{5}{|l|}{6.} \\
\hline \multicolumn{5}{|l|}{7.} \\
\hline \multicolumn{5}{|l|}{8.} \\
\hline 9. & & & & \\
\hline
\end{tabular}




\section{Results}

\subsection{Organoleptic Attributes}

\subsubsection{Fruit and Flesh Color}

The statistically analyzed data is portrayed in Table 2 showing the means for fruit and flesh color of evaluated pear varieties. In this regard, maximum value of hedonic scale among the tested varieties was recorded in Concord (8.25) which is statistically at par with that of Pear Red, followed by Pear White. The fruits of varieties under study gave hedonic scale readings ranged from 8.25 4.20. However, Pear Red possessed best flesh color according to hedonic scale rating among all tested varieties. Kasmiri Nakh variety remained also poor in flesh color compared to other varieties (see Table 3).

\subsubsection{Taste}

Significant results were also recorded about taste of pear varieties. Pear varieties varied greatly in this regard. Pear varieties ranged from $8.40-4.00$ and maximum value of hedonic scale (8.40) for taste was scored by Pear Red followed by Pear selection-1. However, minimum value of hedonic scale (4.00) was noted in Kashmiri Nakh (see Table 3).

\subsubsection{Flavor}

Analysis of variance (ANOVA) at 5\% level of probability about flavor revealed significant varietal effect. Fruits of Bagugosha variety exhibited highest hedonic scale rating for flavor (8.10) which was at par to that of Pear selection-1, Pear Leconte, Pear red and Pear white, followed by Kashmiri Nashpati (5.10) while, least hedonic scale reading (4.60) was observed in fruits of Kasmiri Nakh variety of pear. Detailed results are provided in Table 3.

\subsection{Physical and Geometrical Characteristics}

\subsubsection{Fruit Length}

The detailed quantitative data regarding fruit length of pear is demonstrated in Table 4. The pear variety Kashmiri Nashpati possessed maximum fruit length

Table 3. Organoleptic/Sensory evaluation of pear varieties.

\begin{tabular}{ccccc}
\hline Variety Name & Fruit Color & Flesh Color & Taste & Flavor \\
\hline Pear Leconte & $6.40 \mathrm{bc}$ & $6.30 \mathrm{abc}$ & $8.00 \mathrm{a}$ & $7.00 \mathrm{a}$ \\
Bagugosha & $6.80 \mathrm{bc}$ & $6.52 \mathrm{abc}$ & $7.95 \mathrm{a}$ & $8.10 \mathrm{a}$ \\
Bartlet Pear & $6.30 \mathrm{bc}$ & $6.50 \mathrm{abc}$ & $7.70 \mathrm{a}$ & $7.60 \mathrm{a}$ \\
Concord & $8.25 \mathrm{a}$ & $6.10 \mathrm{bc}$ & $8.00 \mathrm{a}$ & $6.50 \mathrm{ab}$ \\
Pear selection-1 & $7.10 \mathrm{abc}$ & $6.10 \mathrm{bc}$ & $8.30 \mathrm{a}$ & $8.00 \mathrm{a}$ \\
Pear Red & $8.20 \mathrm{a}$ & $7.80 \mathrm{a}$ & $8.40 \mathrm{a}$ & $7.80 \mathrm{a}$ \\
Pear White & $7.50 \mathrm{ab}$ & $7.20 \mathrm{ab}$ & $7.90 \mathrm{a}$ & $7.40 \mathrm{a}$ \\
Kashmiri Nashpati & $6.10 \mathrm{c}$ & $5.10 \mathrm{~cd}$ & $6.10 \mathrm{~b}$ & $5.10 \mathrm{~b}$ \\
Kashmiri Nakh & $4.20 \mathrm{~d}$ & $4.40 \mathrm{~d}$ & $4.00 \mathrm{c}$ & $4.60 \mathrm{c}$ \\
HSD $(P \geq 0.05)$ & 1.3591 & 1.6907 & 1.5217 & 1.7510
\end{tabular}

Any two means not sharing a common letter are significant at $5 \%$ level of probability, $n=4$. 
Table 4. Physio-chemical attributes of pear varieties.

\begin{tabular}{cccccccccccc}
\hline & $\begin{array}{c}\text { Fruit } \\
\text { length } \\
(\mathbf{m m})\end{array}$ & $\begin{array}{c}\text { Fruit } \\
\text { width } \\
(\mathrm{mm})\end{array}$ & $\begin{array}{c}\text { Fruit size } \\
\left(\mathbf{m m}^{2}\right)\end{array}$ & $\begin{array}{c}\text { Fruit } \\
\text { weight } \\
(\mathbf{g})\end{array}$ & $\begin{array}{c}\text { No.of } \\
\text { seeds }\end{array}$ & $\begin{array}{c}\text { Total } \\
\text { soluble } \\
\text { solids (\%) }\end{array}$ & $\begin{array}{c}\text { Titratable } \\
\text { acidity } \\
(\%)\end{array}$ & $\begin{array}{c}\text { Reducing } \\
\text { sugars }\end{array}$ & $\begin{array}{c}\text { Non-Red } \\
\text { ucing } \\
\text { sugars }\end{array}$ & $\begin{array}{c}\text { Total } \\
\text { sugars }\end{array}$ & Yield/plant \\
\hline Pear Leconte & $63.32 \mathrm{~b}$ & $54.46 \mathrm{~b}$ & $3447.2 \mathrm{e}$ & $108.0 \mathrm{de}$ & $7.20 \mathrm{abcd}$ & $14.20 \mathrm{ab}$ & $0.29 \mathrm{e}$ & $6.68 \mathrm{e}$ & $1.41 \mathrm{~b}$ & $8.10 \mathrm{e}$ & 50.20 \\
Bgugosha & $84.36 \mathrm{a}$ & $60.20 \mathrm{a}$ & $5081.3 \mathrm{ab}$ & $205.2 \mathrm{a}$ & $8.20 \mathrm{ab}$ & $15.00 \mathrm{ab}$ & $0.31 \mathrm{~cd}$ & $8.12 \mathrm{a}$ & $1.44 \mathrm{a}$ & $9.56 \mathrm{a}$ & $60.20 \mathrm{e}$ \\
Bartlet Pear & $78.75 \mathrm{a}$ & $53.20 \mathrm{~b}$ & $4197.6 \mathrm{~cd}$ & $153.0 \mathrm{bc}$ & $8.20 \mathrm{ab}$ & $12.80 \mathrm{~b}$ & $0.31 \mathrm{~cd}$ & $7.61 \mathrm{~b}$ & $1.37 \mathrm{c}$ & $9.01 \mathrm{~b}$ & $98.80 \mathrm{a}$ \\
Concord & $78.80 \mathrm{a}$ & $52.80 \mathrm{~b}$ & $4166.8 \mathrm{~cd}$ & $173.0 \mathrm{ab}$ & $5.80 \mathrm{de}$ & $13.80 \mathrm{ab}$ & $0.30 \mathrm{de}$ & $6.89 \mathrm{~d}$ & $1.12 \mathrm{f}$ & $8.08 \mathrm{e}$ & $80.20 \mathrm{~b}$ \\
Small Bagugosha & $62.85 \mathrm{~b}$ & $60.57 \mathrm{a}$ & $3815.7 \mathrm{~cd}$ & $110.6 \mathrm{de}$ & $8.40 \mathrm{a}$ & $15.80 \mathrm{a}$ & $0.33 \mathrm{c}$ & $7.16 \mathrm{c}$ & $1.20 \mathrm{e}$ & $8.36 \mathrm{~d}$ & $40.20 \mathrm{i}$ \\
Pear Red & $65.87 \mathrm{~b}$ & $65.15 \mathrm{a}$ & $4294.9 \mathrm{bc}$ & $137.8 \mathrm{~cd}$ & $5.60 \mathrm{e}$ & $14.80 \mathrm{ab}$ & $0.30 \mathrm{de}$ & $7.60 \mathrm{~b}$ & $1.23 \mathrm{~d}$ & $8.82 \mathrm{c}$ & $70.20 \mathrm{~d}$ \\
Pear White & $67.16 \mathrm{~b}$ & $60.81 \mathrm{a}$ & $4096.5 \mathrm{~cd}$ & $111.0 \mathrm{de}$ & $6.80 \mathrm{bcde}$ & $15.00 \mathrm{ab}$ & $0.31 \mathrm{~d}$ & $7.10 \mathrm{c}$ & $1.19 \mathrm{e}$ & $8.82 \mathrm{c}$ & $75.20 \mathrm{c}$ \\
Kashmiri Nashpati & $87.00 \mathrm{a}$ & $60.17 \mathrm{a}$ & $5242.8 \mathrm{a}$ & $168.8 \mathrm{bc}$ & $6.60 \mathrm{cde}$ & $7.80 \mathrm{c}$ & $0.41 \mathrm{~b}$ & $5.30 \mathrm{f}$ & $1.02 \mathrm{~g}$ & $6.32 \mathrm{~g}$ & $56.00 \mathrm{f}$ \\
Kashmiri Nakh & $44.38 \mathrm{c}$ & $37.39 \mathrm{c}$ & $1660.4 \mathrm{e}$ & $79.0 \mathrm{e}$ & $8.00 \mathrm{abc}$ & $6.60 \mathrm{c}$ & $0.44 \mathrm{a}$ & $5.40 \mathrm{f}$ & $1.01 \mathrm{~g}$ & $6.42 \mathrm{f}$ & $52.00 \mathrm{~g}$ \\
HSD at 5\% & $\mathbf{8 . 6 9}$ & 5.70 & 793.55 & 34.13 & 1.52 & 2.44 & $\mathbf{0 . 0 1}$ & $\mathbf{0 . 1 1}$ & $\mathbf{0 . 0 1}$ & $\mathbf{0 . 0 3}$ & 1.73 \\
\hline
\end{tabular}

Any two means not sharing a common letter are significant at $5 \%$ level of probability. Whereas, $n=4$.

(87.0 mm) which was statistically at par with Bagugosha, Bartlet Pear and Concord having fruit lengths $84.36,78.75,78.80 \mathrm{~mm}$, respectively. However, minimum fruit length was given by Kashmiri Nakh $(44.38 \mathrm{~mm})$.

\subsubsection{Fruit Width}

The statistically analyzed data is presented in Table 4 showing the fruit width of pear varieties. Maximum fruit width was recorded in Pear Red $(65.15 \mathrm{~mm})$ statistically at par with Bagugosha, Pear white, Kashmiri Nashpati and Pear selection-1. However, minimum length of fruits was exhibited by Kashmiri Nakh.

\subsubsection{Fruit Size}

Treatment means after statistical analysis are given in Table 4, illustrating the variation in fruit sizes among the assessed pear varieties. Describing the statistical analysis of recorded data concerning fruit size, the maximum fruit size was observed in Kasmiri Nashpati $\left(5242.8 \mathrm{amm}^{2}\right)$ followed by that of Bagugosha which showed $\left(5081.3 \mathrm{~mm}^{2}\right)$. However, Kasmiri Nakh variety gave the poor performance on this ground (1660.4). Fruit size is the attribute of worth concern in evaluating varietal performance of a fruit. A countable variation in fruit size was seen among the tested varieties.

\subsubsection{Fruit Weight}

The detailed analyzed data about fruit weight is given in Table 4. Comparing the treatment means, it was noticed that the maximum fruit weight was earned by variety Bagugosha (205.2) followed by Bartlet pear (173) which is statistically at par to the Bagugosha and minimum average weight $(79 \mathrm{~g})$ was possessed by the fruits of Kashmiri Nakh variety.

\subsubsection{Number of Seeds}

The recorded data of this variable, after performing ANOVA is demonstrated in Table 4 showing the significant results. All the varieties varied significantly in 
possessing seeds. The maximum average number of seeds (8.20) was found in fruits of variety Bagugosha followed by that of Kashmiri Nakh having average seeds of about (8.00).

\subsection{Biochemical Properties}

\subsubsection{Total Soluble Solids}

The results pertaining to total soluble solids (TSS) is presented in Table 4 . Highly significant results were found on this ground and varieties show great variation in soluble solid contents. The total soluble solid contents were determined ranged from $6.60 \%-15.80 \%$ in the tested pear varieties. However, maximum total soluble solids (15.80\%) were recorded in fruit juice of Pear selection-1 followed by Pear white and Bagugosha which gave $15.00 \%$ TSS. The minimum values $(6.60 \%)$ for total soluble solids were observed in case of Kashmiri Nakh.

\subsubsection{Titratable Acidity}

The results about titratable is presented in Table 4. Statistical data analysis showed significant results for titratable acidity (TA). All the assessed varieties showed diverse behavior about titratable acidity. Titratable acidity of the investigated varieties ranged from $0.29 \%-0.44 \%$. The highest percentage $(0.44 \%)$ of acidity was noted in Kashmiri Nakh followed by that of Kasmiri Nashpati. The lowest value (0.29\%) recorded for titratable acidity in case of Pear Leconte.

\subsubsection{Total Sugars}

Statistically analyzed data for total sugarsis presented in Table 4. The analysis of variance gave highly significant results regarding total sugars exhibited by all the evaluated varieties. The total sugars were determined between the range of 6.32 9.56. The highest sugar level (9.56) was observed in Bagugosha variety followed by Bartlet Pear with sugar level of $9.01 \%$. However, the variety remained poor regarding total sugar level was Kashmiri Nakh possessing $6.32 \%$ total sugars.

\subsubsection{Reducing Sugars}

Statistically analyzed data for reducing sugars is presented in Table 4. Highly significant results were obtained concerning this variable. The recorded level of reducing sugars was ranged from $5.30 \%-8.12 \%$. Describing the treatment means, the maximum reducing sugar was found in Bagugosha followed by Bartlet Pear which possessed $7.61 \%$ of reducing sugars. The minimum (5.30) average reducing sugar was noted in Kasmiri Nashpati.

\subsubsection{Non-Reducing Sugars}

Statistically analyzed data pertaining to non-reducing sugars is presented in $\mathrm{Ta}$ ble 4 . The varieties showed significantly diverse behavior regarding levels of non-reducing sugars. The non-reducing sugars were in the range of $1.01 \%$ $1.44 \%$. The Bgugosha variety was also best for this biochemical attribute followed by that of Pear Leconte. Minimum average non-reducing sugars were produced by the variety Kashmiri Nakh. 


\subsubsection{Yield per Plant}

The detailed data concerning yield per plant is illustrated in Table 4. Highly significant results were found regarding yield variable. The yield per plant fell in the range of $50.20-98.80 \mathrm{~kg}$. The Bartlet Pear was at the top having average fruit yield of $98.80 \mathrm{kgs}$ followed by that of Pear selection-1. The lowest fruit yield per plant was recorded in case of Pear Leconte.

\section{Discussion}

Sugars, acids, minerals and other characteristics like aroma, texture and flavor plays very important role in the nutritional quality and composition of fruits. There are several parameters effect on fruit quality such as environmental conditions, genetic characters and maturity indices [12]. However, pear fruit are crispy, highly flavor and sweet in taste and mostly liked by the consumer.

\subsection{Physical and Geometrical Attributes}

Physical and geometrical characters are considered important in improving the postharvest shelf life and value addition [13]. [14] reported that fruit shape attracts the consumer and improve aesthetic sense. The results revealed that Bagugosha as the prime cultivar followed by Pear selection-1 and Kashmiri Nakh which is in agreement with previous findings of [15].

\subsection{Biochemical and Compositional Traits}

The nature and concentration of these constituents, allied to those of Flesh firmness, titratable acidity, and soluble solids play important roles in maintaining fruit's organoleptic properties, fruitquality, and determining nutritive value [16].

[17] found that total soluble solids may provide proximal information to the consumers in terms of recognizing a more nutritious fruit. Fruit aroma greatly influenced with the contents of soluble solids in pear fruit [18]. It has been reported previously that TSS content of pear cultivars from 6 to $18{ }^{\circ} \mathrm{Brix}$ at different maturity stages, which is inconsistent with our results [19] [20] [21] [22]. Quince (Cydonia oblonga) clones showed higher amount of TSS [23] and similarly TSS values were affected at different harvesting times (morning, noon and evening) in mango [24].

TA is an important quality parameter and a key determinant of fruit taste. Our results are in close agreement with the previously finding that TA content range from 0.10 to $0.46 \mathrm{mg} / 100$ in different pear cultivars [21] [23] [25].

\section{Conclusion}

From the present study it was concluded that pear fruit cultivated in Soon valley has a rich in nutritional profile and sugars. Among the investigated cultivars, Bagugosha was found as the leading cultivar in total sugars, soluble solid contents, fruit weight, taste and flavor; Bartlet pear was dominating in fruit yield, 
while Kashmiri Nashpati was prominent in physical dimensions. The Bagugosha variety may be suggested for commercial cultivation in the region because of its excellent biochemical characteristics. The current study provides first hand compositional information on nine pear cultivars that will be supportive for the researchers and growers in developing postharvest management systems and industrialization of pear fruit in the area.

\section{Conflicts of Interest}

The authors declare no conflicts of interest regarding the publication of this paper.

\section{References}

[1] Ahmed, M., Anjum, M.A., Khan, Z., Awan, M.S. and Rabbani, M.A. (2011) Assessment of Variability in Fruit Quality Parameters of Pyrus Germplasm Collected from Azad Jammu and Kashmir (Pakistan). Pakistan Journal of Botany, 43, 971-981.

[2] Senser, F., Scherz, H. and Munchen, G. (1999) Tablasde Composicion de Alimentos. 2nd Edition, Editorial Acribia, Zaragoza.

[3] Silos, E.H., Morales, F.L., Castro, J.A., Valverde, E., Lara, F. and Lopez, O. (2003) Chemical and Biochemical Changes in Prickly Pears with Different Ripening Behaviours. Nahrung, 47, 334-338. https://doi.org/10.1002/food.200390077

[4] USDA (2011) Economic National Nutrition Database for Standard References. http://www.nal.usda.gov

[5] Sha, S.F., Li, J.C., Wu, J. and Zhang, S.L. (2011) Characteristics of Organic Acids in the Fruit of Different Pear Species. African Journal of Agricultural Research, 6, 2403-2410.

[6] Mahammad, M.U., Kamba, A.S., Abubakar, L. and Bagna, E.A. (2010) Nutritional Composition of Pear. African Journal of Food Science and Technology, 1, 76-81.

[7] Fruits Vegetables and Condiments. http://www.amis.pk/files/F\&V\%20Statistics\%202015-16.pdf

[8] Ozturk, I., Ercisli, S., Kalkan, F. and Demir, B. (2009) Some Chemical and Physico-Mechanical Properties of Pear Cultivars. African Journal of Biotechnology, 8, 687-693.

[9] AOAC (2000) Official Methods of Analysis. 17th Edition, Association of Official Analytical Chemists, Arlington.

[10] Krum, J.K. (1955) Truest Evaluations in Sensory Panel Testing. Food Engineering, 27, 74-83.

[11] Steel, R.D., Torrie, J.H. and Dickeyl, D. (1997) Principals and Procedures of Statistics: A Biometrical Approac. 3rd Edition, McGraw-Hill Book Co., New York.

[12] Hudina, M. and Stampar, F. (2005) The Correlation of the Pear (Pyrus communis L.) cv. "Williams" Yield Quality to the Foliar Nutrition and Water Regime. Acta Agriculturae Slovenica, 85, 179-185.

[13] Demir, F. and Kalyoncu, I.H. (2003) Some Nutritional, Pomological and Physical Properties of Cornelian Cherry (Cornus mas L.). Journal of Food Engineering, 60, 335-341. https://doi.org/10.1016/S0260-8774(03)00056-6

[14] Omobuwajo, T.O., Sanni, L.A. and Olajide, L.O. (2000) Physical Properties of Ackee Apple (Blighia sapida) Seeds. Journal of Food Engineering, 45, 43-48. 
https://doi.org/10.1016/S0260-8774(00)00040-6

[15] Hussain, S., Masud, T., Ali, S., Bano, R. and Ali, A. (2013) Some Physico-Chemical Attributes of Pear (Pyrus communis L.) Cultivars Grown in Pakistan. International Journal of Biosciences, 3, 206-215.

[16] Li, X., Li, X., Wang, T. and Gao, W. (2016) Nutritional Composition of Pear Cultivars (Pyrus spp.). In: Simmonds, M.S.J. and Preedy, V.R., Eds., Nutritional Composition of Fruit Cultivars, Academic Press, Cambridge, 573-608.

[17] Drogoudi, P.D., Michailidis, Z. and Pantelidis, G. (2008) Peel and Flesh Antioxidant Content and Harvest Quality Characteristics of Seven Apple Cultivars. Scientia Horticulturae, 115, 149-153. https://doi.org/10.1016/j.scienta.2007.08.010

[18] Vangdal, E. (1985) Quality Criteria for Fruit for Fresh Consumption. Acta Agriculturae Scandinavica, 35, 41-47. https://doi.org/10.1080/00015128509435757

[19] Janick, J. (2006) “H2-169” Ambrosia Pear. Horticultural Science, 41, 467.

[20] Faisal, F. and Ahmed, M.K. (2007) Effect of Concentrations and Date of Spraying Sitofex (CPUU) on Yield and Quality of Le-Conte Pear Fruits. African Crop Science Conference Proceedings, 8, 523-527.

[21] Sanchez, G.A.C., Angel, G.I. and Maria, I.G. (2003) Comparative Study of Six Pear Cultivars in Terms of Their Phenolic and Vitamin C Contents and Antioxidant Capacity. Journal of the Science of Food and Agriculture, 83, 995-1003. https://doi.org/10.1002/jsfa.1436

[22] Chen, J., Wang, Z., Wub, J., Wang, Q. and Hub, X. (2007) Chemical Compositional Characterization of Eight Pear Cultivars Grown in China. Food Chemistry, 104, 268-275. https://doi.org/10.1016/j.foodchem.2006.11.038

[23] Guisado, R., Hernandez, F., Melgarejo, P., Legua, P., Martinez, R. and Martinez, J. (2009) Chemicalmorphological and Organoleptical Characterization of Five Spanish Quince Tree Clones (Cydoniaoblonga Miller). Scientia Horticulturae, 122, 491-496. https://doi.org/10.1016/j.scienta.2009.06.004

[24] Amin, M., Malik, A.U., Mazhar, M.S., Din, I.U., Khalid, M.S. and Ahmad, S. (2009) Mango Fruit Desapping in Relation to Time of Harvesting. Pakistan Journal of Botany, 40, 1587-1593.

[25] Arzani, K., Khoshghalb, H., Malakouti, M.J. and Barzegar, M. (2011) Total Oxalate Soluble Pectin Concentration in Asian Pear (Pyrus serotina Rehd) Fruit in Relation to Ripening, Storage and Internal Browning Disorder. Journal of Agricultural Science and Technology, 13, 611-626. 